Int. J. Electrochem. Sci., 13 (2018) $1614-1628$

International Journal of

ELECTROCHEMICAL

SCIENCE

www.electrochemsci.org

\title{
Effect of the Degree of Rolling Reduction on the Stress Corrosion Cracking Behavior of SUS 304 Stainless Steel
}

\author{
Shanlin $\mathrm{He}^{*}$, Daming Jiang \\ School of Materials Science and Engineering, Harbin Institute of Technology, Harbin 150001, China \\ *E-mail: 11b909025@ hit.edu.cn
}

doi: $10.20964 / 2018.02 .56$

Received: 23 October 2017 / Accepted: 14 December 2017 / Published: 28 December 2017

In this study, SUS 304 stainless steel was cold rolled with various degrees of rolling reduction. The microstructure and stress corrosion cracking behavior before and after cold rolling were investigated. Electrochemical noise measurements coupled with slow strain rate testing were performed in a 3.5\% $\mathrm{NaCl}$ solution. The results indicated that the microstructure of SUS 304 stainless steel transformed from a single austenite phase into a compound with both the martensite phase and original austenite phase after cold rolling. The martensite phase increased with an increase in the degree of rolling reduction. During the slow strain rate test process, mechanical properties such as the breaking elongation and tension strength, corrosion resistance and stress corrosion cracking resistance significantly decreased after cold rolling. All the rolled specimens, the mechanical properties were highest for the specimen when the degree of rolling reduction was $14 \%$. The stress corrosion cracking susceptibility depended on the crack initiation time during the slow strain rate test process.

Keywords: SUS 304 stainless steel; cold rolling; stress corrosion cracking; electrochemical noise; slow strain rate test

\section{FULL TEXT}

(C) 2018 The Authors. Published by ESG (www.electrochemsci.org). This article is an open access article distributed under the terms and conditions of the Creative Commons Attribution license (http://creativecommons.org/licenses/by/4.0/). 